\title{
Fresh-cut carrot (cv. Nantes) quality as affected by abiotic stress (heat shock and UV-C irradiation) pre-treatments
}

\author{
Carla Alegriaa ${ }^{a, b}$, Joaquina Pinheiro ${ }^{a}$, Margarida Duthoit ${ }^{a}$, Elsa M. Gonçalves ${ }^{a}$, \\ Margarida Moldão-Martins ${ }^{\mathrm{b}}$, Marta Abreu ${ }^{\mathrm{a}, *}$ \\ ${ }^{a}$ UITA/INIA, Instituto Nacional de Recursos Biológicos, Estrada Paço do Lumiar, 22, Edifício S, 1649-038 Lisboa, Portugal \\ ${ }^{\mathrm{b}}$ CEER - Biosystems Engineering, Instituto Superior de Agronomia, Universidade Técnica de Lisboa, Tapada da Ajuda, 1349-017 Lisboa, Portugal
}

\section{A R T I C L E I N F O}

\section{Article history:}

Received 19 October 2011

Received in revised form

16 January 2012

Accepted 8 March 2012

\section{Keywords:}

Abiotic stress

Heat shock

UV-C radiation

Fresh-cut carrot

Quality

\begin{abstract}
A B S T R A C T
Abiotic stresses such as heat shock and UV-C irradiation can be used to induce synthesis of bioactive compounds and to prevent decay in fresh-cut fruits and vegetables. This study aimed to evaluate the effects of heat shock and UV-C radiation stress treatments, applied in whole carrots, on the overall quality of fresh-cut carrot cv. Nantes during storage $\left(5^{\circ} \mathrm{C}\right)$. Heat shock $\left(\mathrm{HS}, 100{ }^{\circ} \mathrm{C} / 45 \mathrm{~s}\right)$ and UV-C $\left(0.78 \pm 0.36 \mathrm{~kJ} / \mathrm{m}^{2}\right)$ treated samples had higher phenolic content and exhibited reduced POD activities during storage when compared to control (Ctr) samples ( $200 \mathrm{mg} / \mathrm{L}$ free chlorine/1 min). All samples showed reduced carotenoid content considering raw material. Nonetheless, UV samples registered a three-fold increase in carotenoid content in subsequent storage. Fresh-cut carrot colour showed a continuous increase in whiteness index (WI) values during storage regardless of treatment without impairing visual quality. Respiratory metabolism was affected by both abiotic stress treatments since reduced $\mathrm{O}_{2} / \mathrm{CO}_{2}$ rates were found, more significant in $\mathrm{HS}$ samples. The decontamination effect was more expressive in HS samples, where a $2.5 \log _{10} \mathrm{cfu} / \mathrm{g}$ reduction in initial microbial load and reduced microbial growth were achieved.
\end{abstract}

(c) 2012 Elsevier Ltd. All rights reserved.

\section{Introduction}

The market of fresh-cut fruits and vegetables (F\&V) (washed, cut, packaged and refrigerated products) is the fastest growing segment on the F\&V market in the European Union (EU) and the main reason for its success rely on their optimal characteristics, offering consumers highly nutritious, convenient and healthy food while still maintaining the freshness that consumers have come to expect (Ragaert, Verbeke, Devlieghere, \& Debevere, 2004). However, minimal processing operations damage F\&V tissue integrity which triggers deteriorative processes including oxidative browning, tissue softening, water loss and development of undesirable flavours and odours. In addition, the removal of the natural protective epidermal barrier and the increase in moisture and dissolved sugars on the surface provide ideal conditions for microbial colonization and proliferation (Guerzoni, Gianotti, Corbo,

\footnotetext{
* Corresponding author. Tel.: +351 21 7127101; fax: +351 217127162.

E-mail addresses: csmalegria@gmail.com (C. Alegria), joaquina.pinheiro@ gmail.com (J. Pinheiro), margarida.duthoit@inrb.pt (M. Duthoit), elsa.goncalves@ inrb.pt (E.M. Gonçalves), marta.abreu@inrb.pt, marta.mmn.abreu@gmail.com (M. Abreu).
}

\& Sinigaglia, 1996). According to this, the hurdle technology envisions the combination of at least two different techniques in the preservation strategy and involves the intelligent selection of hurdles to achieve a specified outcome, designed for each fresh-cut product (Corbo, Speranza, Campaniello, Amato, \& Sinigaglia, 2010).

Among the preservation techniques that are currently in use by the fresh-cut industry, e.g. antioxidants, chlorine and modified atmosphere packaging, several drawbacks are identified which have led to the development of alternatives. Heat treatments are generally effective in reducing microbial levels and under suitable time/temperature conditions, proved to be an effective methodology to control microbial growth in several fresh-cut F\&V (Aguayo, Escalona, \& Artés, 2008; Klaiber, Baur, Wolf, Hammes, \& Carle, 2005; Li, Brackett, Shewfelt, \& Beuchat, 2001). Improvements in keeping quality and reducing incidence of storage diseases in various horticultural crops have been described by products immersion in hot-water baths (Delaquis, Stewart, Toivonen, \& Moyls, 1999; Loaiza-Velarde, Mangrich, Campos-Vargas, \& Saltveit, 2003; Loaiza-Velarde, Tomás-Barberán, \& Saltveit, 1997). In addition, several biochemical pathways are likely to be involved in stress responses imposed by heat, namely synthesis of heat shock proteins, interruption of normal cellular protein synthesis, 
including quality-related enzymes (polyphenoloxidase, peroxidase, phenylalanine ammonia-lyase and pectin methylesterase) and also changes in the kinetic characteristics of existing enzymes (LoaizaVelarde et al., 2003; Saltveit, 2000). Recently, UV-C treatments have also been investigated as an alternative sanitizing methodology to assure fresh-cut product safety, still of major concern. Reports on the effectiveness of UV-C treatments in reducing microbial loads on the surface of fresh-cut F\&V and particularly over pathogens are available (Allende, McEvoy, Luo, Artés, \& Wang, 2006; Allende, Tomás-Barberán, \& Gil, 2006; Fonseca \& Rushing, 2006; Schenk, Guerrero, \& Alzamora, 2007). As a postharvest treatment, UV-C irradiation has proven beneficial to reduce respiration rates (Baka, Mercier, Corcuff, Castalgne, \& Arul, 1999), to rot development control (Erkan, Wang, \& Krizek, 2001), and to delay senescence and ripening in different F\&V (Perkins-Veazie, Collins, \& Howard, 2008). More recently, González-Aguilar, Villegas-Ochoa, Martínez-Téllez, Gardea, and Ayala-Zavala (2007) and Erkan, Wang, and Wang (2008) found that UV-C irradiation improved the antioxidant capacity of fresh-cut mangoes and in strawberries, respectively, during storage. For these reasons, the use of heat shock and ultraviolet- $C$ radiation, alone or in combination, are promising treatments to minimize quality losses during storage of fresh-cut produce (Allende, Tomás-Barberán, et al., 2006).

The present research was aimed to: (1) evaluate the singular effects of heat shock and UV-C radiation stress pre-treatments in whole carrots on the total phenolic and carotenoid contents, POD activity and respiratory metabolism of the shredded carrot during refrigerated storage $\left(5{ }^{\circ} \mathrm{C}, 10\right.$ days); (2) Examine the singular effects of heat shock and UV-C radiation stress pre-treatments as alternatives to chlorine regarding product decontamination and microbial development during storage $\left(5{ }^{\circ} \mathrm{C}, 7\right.$ days).

\section{Materials and methods}

\subsection{Plant material}

A lot of $100 \mathrm{~kg}$ of carrots (Daucus carota L. cv. Nantes) was purchased at a local market and maintained at $5{ }^{\circ} \mathrm{C}\left( \pm 1{ }^{\circ} \mathrm{C}\right)$ until use. From the initial lot, a $10 \%$ sampling was used to conduct a physical-chemical and microbial characterization of raw fresh carrot following the same analytical protocol as for samples. The results are shown in Table 1.

Table 1

Physical-chemical and microbiological characterization of raw fresh carrot cv. Nantes (raw material, unprocessed).

\begin{tabular}{|c|c|}
\hline Quality measurements & Mean \pm SD \\
\hline \multicolumn{2}{|l|}{ Physical-chemical attributes } \\
\hline \multicolumn{2}{|l|}{ Colour $^{\mathrm{a}}$} \\
\hline$L^{*}$ & $60.8 \pm 3.3$ \\
\hline$a^{*}$ & $23.1 \pm 1.4$ \\
\hline$b^{*}$ & $60.6 \pm 2.6$ \\
\hline Whiteness index (WI) & $24.1 \pm 1.8$ \\
\hline Total phenolic content ${ }^{\mathrm{b}}$ (mg GAE/100 g) & $21.0 \pm 0.9$ \\
\hline Total carotenoid content ${ }^{\mathrm{b}}(\mathrm{mg} / 100 \mathrm{~g})$ & $27.5 \pm 0.4$ \\
\hline Peroxidase activity ${ }^{\mathrm{b}}(\mathrm{U} / \mathrm{g})$ & $65.4 \pm 5.6$ \\
\hline \multicolumn{2}{|l|}{ Microbiological load } \\
\hline Total mesophilic aerobic count ${ }^{\mathrm{c}}\left(\log _{10} \mathrm{cfu} / \mathrm{g}\right)$ & $4.5 \pm 0.1$ \\
\hline \multicolumn{2}{|l|}{ a Data represents the mean of 27 values. } \\
\hline \\
\hline \multicolumn{2}{|c|}{ 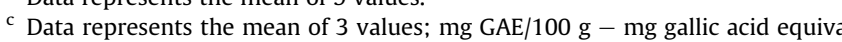 } \\
\hline
\end{tabular}

\subsection{Sample preparation}

The remaining $90 \mathrm{~kg}$ of carrot was equally divided into three groups and used to prepare treated and control samples of freshcut carrot (shredded). Carrots submitted to heat and UV pretreatments and further minimal processed were identified as HS and UV samples, respectively. Carrots only submitted to minimal processing according to an industrial practice (Fig. 1), were identified as control samples (Ctr samples). The abiotic stress pretreatments (heat shock and UV-C irradiation) were applied $24 \mathrm{~h}$ before processing since, according to Lamikanra and Watson (2007), favourable changes in the metabolic rates of qualityrelated enzymes (e.g. Peroxidase, POD) are achieved during storage using this hold-up period before processing.

\subsubsection{Heat shock pre-treatment}

Heat shock (HS) samples were prepared by immersion of whole peeled carrots in hot-water at previously optimized pre-cut conditions of $100{ }^{\circ} \mathrm{C}$ for $45 \mathrm{~s}$ (Alegria et al., 2009, 2010) as follows: Potable tap water was heated to the specified temperature $\left(100^{\circ} \mathrm{C} \pm 0.5^{\circ} \mathrm{C}\right)$ using a thermostatically-controlled water bath (with agitation; 50 L nominal capacity; Edelstahl Rost-Frei, Schwabach, Germany) and temperature was monitored continuously with T-type thermocouples. Heat pre-treated samples were then cooled in ice-cold potable water $\left(0^{\circ} \mathrm{C}\right)$ for $5 \mathrm{~min}$, paper dried and held at $5{ }^{\circ} \mathrm{C}$ for $24 \mathrm{~h}$ until shredding operations (Fig. 1). In heat pre-treated samples, no further decontamination procedure was used during minimal processing since heat shock is also regarded as an alternative to chlorine decontamination.

\subsubsection{UV-C irradiation pre-treatment}

The UV-C apparatus consists of two reflector racks placed longitudinally and each one is equipped with unfiltered germicidal emitting lamps $(\lambda=254 \mathrm{~nm}$ ) (TUV 15W/G15 T8, Phillips, The Netherlands). Lamps are located $15 \mathrm{~cm}$ above the illumination area. A wooden box $(43 \mathrm{~cm}(w) \times 50 \mathrm{~cm}(l) \times 24 \mathrm{~cm}(h))$ covered with a reflector inner layer (food grade aluminium foil) and supported by a metal framework enclosed the UV-C lamps, reflectors and treatment area, providing UV protection for the operator. Prior to use, lamps were turned on and allowed to stabilize for a period of time not less than $15 \mathrm{~min}$. In order to determine the UV-C irradiation intensity of the lamps, an HD2102.2 photoradiometer (Delta Ohm, Padova, Italy) equipped with an LP471 UVC probe (Delta Ohm, Padova, Italy), was used. Whole peeled carrots were placed in a single layer on the illumination area at the fixed distance and rotated manually $\left(180^{\circ}\right)$ in order to ensure even exposure to UV light of both carrots' hemispheres. Treatment time was kept constant ( 2 min at each carrot hemisphere) and the applied UV-C dose was calculated from a mean of 10 readings $(0.78 \pm 0.36 \mathrm{~kJ} /$ $\mathrm{m}^{2}$ ). After the pre-treatment, the whole carrots were held at $5^{\circ} \mathrm{C}$ for $24 \mathrm{~h}$ until shredding operations. As for HS samples, in UV sample preparation, no further decontamination procedure was used during minimal processing for the above mentioned reason.

\subsubsection{Minimal processing operations}

Minimal processing operations were carried out according to an industrial practice: carrots were peeled, shredded (Dito MV50 shredder), decontaminated with chlorinated water $(200 \mathrm{mg} / \mathrm{L}$ free chlorine/1 min), rinsed, dried (manual centrifuged), and packed in portions of $125 \mathrm{~g}$ using bags of $35 \mu \mathrm{m}$ bioriented polypropylene $(200 \times 110 \mathrm{~mm})($ Amcor Flexibles Neocel - Embalagens Lda., Lisboa, Portugal). The permeability of the film was with oxygen and carbon dioxide transmission rates of $1100 \mathrm{~cm}^{3} / \mathrm{m}^{2} \cdot 24 \mathrm{~h} \cdot \mathrm{atm}$ and $3000 \mathrm{~cm}^{3} / \mathrm{m}^{2} \cdot 24 \mathrm{~h} \cdot \mathrm{atm}$ at $23^{\circ} \mathrm{C}$, respectively. The bags were heatsealed and stored at $5{ }^{\circ} \mathrm{C}$ (S600 Pharma, Fitoclima, Aralab - 


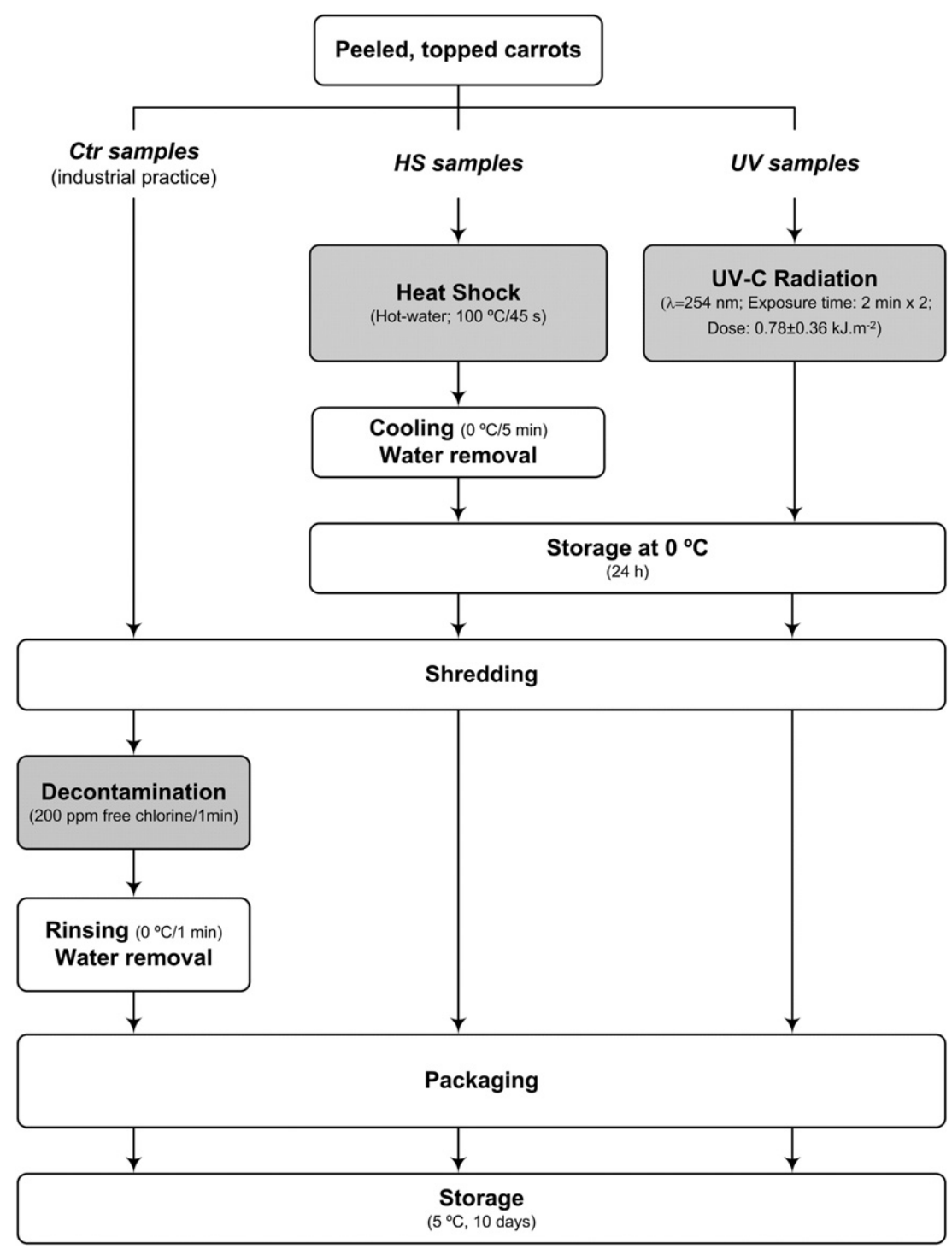

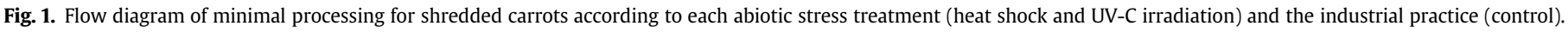

Equipamentos de Laboratório e Electromecânica Geral Lda., Portugal) for 10 days.

\subsection{Analytical procedures}

Analytical procedures were carried out in triplicate (independent bags), unless otherwise stated, on five sampling dates, i.e. day 0 (within $2 \mathrm{~h}$ from minimal processing), 3, 5, 7 and 10.

\subsubsection{Colour}

Colour measurements were performed in a colorimeter (Minolta Chroma Meter CR 300, Osaka, Japan) by measuring the CIE $L^{*} a^{*} b^{*}$ parameters ( $C$ illuminant). The instrument was calibrated using a standard white tile $\left(L^{*}=97.10, a^{*}=0.19, b^{*}=1.95\right)$. A total of 27 measurements were made per sample bag and the $L^{*} a^{*} b^{*}$ data was then transformed to the whiteness index score (WI) according to the equation $\mathrm{WI}=100-\left[\left(100-L^{*}\right) 2+a^{*} 2+b^{*} 2\right] 0.5$ (Bolin \& Huxsoll, 1991).

\subsubsection{Total phenolic content}

Total phenolic content (TPC) was determined using the Folin-Ciocalteu reagent (Singleton \& Rossi, 1965). Fresh-cut carrot samples were homogenized with $70 \mathrm{~mL} / 100 \mathrm{~mL}$ methanol $(1: 1$, w:v) using a Yellow line DI 25 basic polytron (IKA-Werke GmbH \& Co. KG). After centrifugation $(5000 \mathrm{rpm} \times 20 \mathrm{~min} ; 4 \mathrm{~K} 15$ Sigma Laboratory Centrifuges, rotor 11,150 ) at $4{ }^{\circ} \mathrm{C}, 0.1 \mathrm{~mL}$ aliquot of the supernatant (three replicates) was mixed in $5 \mathrm{~mL}$ of diluted Folin-Ciocalteu reagent $(1 / 10, \mathrm{v} / \mathrm{v})$ and $4 \mathrm{~mL}$ of $7.5 \mathrm{~g} / 100 \mathrm{~mL}$ $\mathrm{Na}_{2} \mathrm{CO}_{3}$. This mixture was then placed in a water bath at $45^{\circ} \mathrm{C}$ for $15 \mathrm{~min}$, after which the absorbance at $765 \mathrm{~nm}$ was measured, using gallic acid as standard. Triplicate samples were performed for each sample type and the results were expressed as $\mathrm{mg}$ of gallic acid equivalent per $100 \mathrm{~g}$ fresh weight ( $\mathrm{fw}$ ).

\subsubsection{Total carotenoid content}

The extraction procedure for determination of the total carotenoid content was followed according to the method described by Gorocica-Buenfil, Fluharty, Bohn, Schwartz, \& Loerch (2007) and the established spectrophotometric analysis for respective quantification was carried out according to the method described by Biehler, Mayer, Hoffman, Krause, \& Bohn (2010), and results expressed as mg/100 g fw. Total carotenoid content was only determined at days 0,5 and 7 of storage. 


\subsubsection{Peroxidase activity}

Peroxidase (POD) activity was determined as described previously in Alegria et al. (2010).

One unit of POD activity was defined as an increase in absorbance of 1.0 at $470 \mathrm{~nm}$ per min per mL enzyme crude extract. POD activity was expressed as enzyme units per gram fw $(\mathrm{U} / \mathrm{g})$.

\subsubsection{Headspace analysis}

Headspace gas samples were taken with a hypodermic needle through an adhesive septum previously fixed on the bags and were analyzed for oxygen and carbon dioxide concentrations (\%) using a Checkmate $9900 \mathrm{O}_{2} / \mathrm{CO}_{2}$ gas analyzer (PBI-Dansensor, Ringsted, Denmark). On each sampling day, 5 bags were analyzed per sample type.

\subsubsection{Total mesophilic aerobic count}

Total mesophilic aerobic count (TAPC) was preformed according to EN ISO 4833, 2003 in triplicate. This analysis was conducted just after minimal processing (day 0 ) and after 7 days of storage (expected shelf-life period for fresh-cut carrot according to Alegria et al., 2010). Microbial counts were expressed as $\log _{10}(\mathrm{cfu} / \mathrm{g})$.

\subsubsection{Informal sensory colour evaluation}

For informal sensorial colour evaluation, it was requested to an untrained panel of 10 assessors to compare all samples with freshly-cut carrot at each sampling day and to address if differences in colour were noticeable among the 3 sample types.

\subsection{Statistical analysis}

Data from the trial was subjected to analysis of variance (Oneway ANOVA) using the Statistica ${ }^{\mathrm{TM}} \mathrm{V} .6 .1$ Software from Statsoft (StatSoft Inc., 2002). Statistically significant differences $(P<0.05)$ between samples were determined according to Tukey Honestly Significant Difference (HSD) test.

\section{Results \& discussion}

\subsection{Colour}

Colour changes, expressed as WI (Table 2), show an increase during storage in all samples $(P<0.05)$. HS samples had significantly lower WI mean scores in comparison to Ctr and UV samples, until day 3. By the end of storage, all samples had identical WI values $(P>0.05)$.

Increases in WI values during storage are usually correlated to surface whitening, a well-documented defect of shredded carrot, and has been attributed to surface dehydration and/or lignin synthesis (Barry-Ryan \& O’Beirne, 1998). Whitening control in heattreated shredded carrot has been previously reported (Alegria et al., 2010; Howard, Griffin, \& Lee, 1994) and correlated with peroxidase inhibition. However, objective colour measurements (expressed as WI) did not match the informal sensorial colour evaluation where, during the entire storage period, none of the 10 members of the panel were able to detect differences between the samples and freshly-cut carrot.

\subsection{Total phenolic content}

At day 0 all samples showed a significant decrease $(P<0.05)$ in total phenolic content (TPC) of $c a .37 \%, 24 \%$ and $17 \%$ for Ctr, UV and HS samples, respectively (Table 2) when compared to the fresh content of $21.0 \pm 0.9 \mathrm{mg} \mathrm{GAE} / 100 \mathrm{~g}$.

Loss in phenolic content in grated carrot as a result of chlorinated-water treatment could be attributed mainly to leaching phenomena, as reported by Vandekinderen et al. (2008). Heatinduced losses of phenolic compounds could be attributed to phenolic thermal degradation (autoxidation or breakdown). For instance, blanching vegetables in boiling water is responsible for losses in phenolic content up to $40 \%$ (e.g., spinach, cabbage, peas or squash) (Turkmen, Sari, \& Velioglu, 2005). It is known that oxidizing treatments such as UV-C light are likely to be involved in photo-oxidation reactions in plants with production of free radicals (Maharaj, Arul, \& Nadeau, 1999), which can lead to phenolic consumption as antioxidants. Losses in total phenolic content were also observed in strawberries by Pan, Vicente, Martínez, Chaves, \& Civello (2004), 1 day after UV-C treatment $\left(4.16 \mathrm{~kJ} / \mathrm{m}^{2}\right)$. However, also in strawberry, Allende, Marín, Buendía, Tomás-Barberán, \& Gil (2007) observed maintenance in phenolic content just after UV-C treatment $\left(1 \mathrm{~kJ} / \mathrm{m}^{2}\right)$.

In general, HS and UV samples showed higher phenolic content during storage than $\mathrm{Ctr}$ samples. HS samples showed a significant $(P<0.05)$ TPC increase at day $7(30.2 \pm 0.8 \mathrm{mg}$ GAE/100 g) surpassing that of raw carrot $(21.0 \pm 0.9 \mathrm{mg}$ GAE/100 g). The

\section{Table 2}

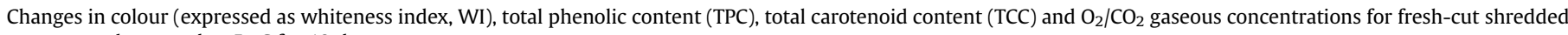
carrot samples stored at $5{ }^{\circ} \mathrm{C}$ for 10 days.

\begin{tabular}{|c|c|c|c|c|c|c|}
\hline Sample ID & Storage time (days) & Whiteness index & TPC (mg GAE/100 g) & $\mathrm{TCC}(\mathrm{mg} / 100 \mathrm{~g})$ & $\mathrm{O}_{2}(\%)$ & $\mathrm{CO}_{2}(\%)$ \\
\hline Raw material & - & - & $21.0^{g} \pm 0.9$ & $27.5^{\mathrm{b}} \pm 0.4$ & - & - \\
\hline \multirow[t]{5}{*}{ Ctr sample } & 0 & $25.5^{\mathrm{b}} \pm 2.1$ & $13.3^{\mathrm{ab}} \pm 1.5$ & $11.9^{\mathrm{e}} \pm 0.0$ & $21.0^{\mathrm{d}} \pm 0.0$ & $0.0^{\mathrm{a}} \pm 0.0$ \\
\hline & 3 & $27.3^{\mathrm{c}} \pm 2.4$ & $15.6^{\mathrm{bcd}} \pm 1.3$ & nd & $7.2^{\mathrm{b}} \pm 2.2$ & $10.1^{\mathrm{bc}} \pm 1.0$ \\
\hline & 5 & $28.2^{\text {cde }} \pm 2.6$ & $16.3^{\text {cdef }} \pm 2.2$ & $19.7^{\mathrm{a}} \pm 0.3$ & $1.1^{\mathrm{a}} \pm 0.9$ & $13.8^{\text {def }} \pm 2.1$ \\
\hline & 7 & $28.0^{\text {cde }} \pm 2.2$ & $12.3^{\mathrm{a}} \pm 1.9$ & $8.9^{c} \pm 0.0$ & $0.2^{\mathrm{a}} \pm 0.1$ & $17.7^{\mathrm{ghi}} \pm 2.3$ \\
\hline & 10 & $28.9^{\mathrm{e}} \pm 2.7$ & $16.9^{\text {cdef }} \pm 0.8$ & nd & $0.2^{\mathrm{a}} \pm 0.2$ & $20.2^{\mathrm{i}} \pm 1.5$ \\
\hline \multirow[t]{5}{*}{ HS sample } & 0 & $24.2^{\mathrm{a}} \pm 2.2$ & $17.3^{\text {def }} \pm 2.3$ & $19.9^{\mathrm{a}} \pm 0.2$ & $21.0^{\mathrm{d}} \pm 0.0$ & $0.0^{\mathrm{a}} \pm 0.0$ \\
\hline & 3 & $25.9^{b} \pm 3.0$ & $18.7^{\mathrm{fg}} \pm 1.6$ & nd & $12.1^{\mathrm{c}} \pm 1.0$ & $7.4^{\mathrm{b}} \pm 0.9$ \\
\hline & 5 & $27.6^{\mathrm{cd}} \pm 2.5$ & $18.9^{\mathrm{fg}} \pm 2.1$ & $25.0^{g} \pm 0.6$ & $5.5^{\mathrm{b}} \pm 0.8$ & $9.8^{\mathrm{bc}} \pm 2.4$ \\
\hline & 7 & $27.2^{\mathrm{c}} \pm 2.7$ & $30.1^{\mathrm{h}} \pm 1.1$ & $13.6^{\mathrm{f}} \pm 0.2$ & $2.1^{\mathrm{a}} \pm 1.5$ & $12.8^{\text {cde }} \pm 1.9$ \\
\hline & 10 & $28.2^{\text {cde }} \pm 2.7$ & $17.5^{\text {def }} \pm 1.1$ & nd & $0.2^{\mathrm{a}} \pm 0.0$ & $14.6^{\mathrm{efg}} \pm 1.3$ \\
\hline \multirow[t]{5}{*}{ UV sample } & 0 & $25.2^{\mathrm{ab}} \pm 1.8$ & $16.0^{\text {cde }} \pm 1.1$ & $10.0^{\mathrm{d}} \pm 0.0$ & $21.0^{\mathrm{d}} \pm 0.0$ & $0.0^{\mathrm{a}} \pm 0.0$ \\
\hline & 3 & $27.3^{c} \pm 2.0$ & $18.5^{\mathrm{efg}} \pm 0.7$ & nd & $10.7^{c} \pm 2.4$ & $8.0^{\mathrm{b}} \pm 1.3$ \\
\hline & 5 & $28.2^{\text {cde }} \pm 2.2$ & $18.8^{\mathrm{fg}} \pm 1.1$ & $20.2^{\mathrm{a}} \pm 0.9$ & $5.4^{\mathrm{b}} \pm 1.8$ & $10.6^{\mathrm{bcd}} \pm 0.9$ \\
\hline & 7 & $28.7^{\mathrm{de}} \pm 2.4$ & $14.3^{\mathrm{abc}} \pm 1.9$ & $28.8^{\mathrm{h}} \pm 0.0$ & $0.6^{\mathrm{a}} \pm 0.7$ & $16.1^{\mathrm{fgh}} \pm 3.0$ \\
\hline & 10 & $28.9^{\mathrm{e}} \pm 2.3$ & $17.0^{\text {cdef }} \pm 1.1$ & nd & $0.1^{\mathrm{a}} \pm 0.0$ & $18.0^{\mathrm{hi}} \pm 1.6$ \\
\hline
\end{tabular}

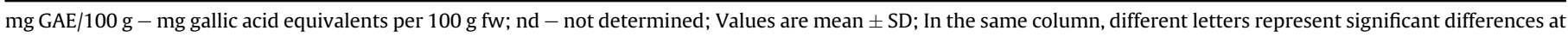
$P=0.05$ (Tukey HSD test). 
enhancement of bioactive compounds (e.g. vitamins C and E, carotenoids and phenolic compounds) in fresh and processed fruits and vegetables using abiotic stresses (wounding, heat shock, UV irradiation, among others) have been reported in previous studies (Heredia \& Cisneros-Zevallos, 2009; Lavelli, Pagliarini, Ambrosoli, Minati, \& Zanoni, 2006) due to changes in several phytochemical pathways. The wound-induced accumulation of phenolic compounds due to phenylpropanoid pathway activation is well characterized in carrots and lettuce (Jacobo-Velazquez, MartínezHernández, del C Rodríguez, Cao, \& Cisneros-Zevallos, 2011; Ke \& Saltveit, 1989).

\subsection{Total carotenoid content}

Total carotenoid content (TCC) of all samples decreased considerably just after minimal processing (Table 2). The highest loss $(P<0.05)$ was registered in UV samples (64\%) followed by $\mathrm{Ctr}$ (57\%) and HS (28\%) samples when compared to the fresh content. Thereafter, carotenoid levels of all samples increased $(P<0.05)$ at day 5 of storage followed by a reduction $(P<0.05)$ on the last day of analysis, except for UV samples. Moreover, UV samples exhibited an interesting behaviour during storage since a consistent increase was observed in TCC, reaching levels three fold higher at day 7 than at day 0 (10.0 $\pm 0.0 v s .28 .8 \pm 0.0 \mathrm{mg} / 100 \mathrm{~g})$. In agreement are the findings of Liu, Zabaras, Bennett, Aguas, \& Woonton (2009), who reported that during postharvest storage, carotenoid levels in UV treated tomato did not change during the early stages of storage and started to increase thereafter. This behaviour is of upmost importance since, in human diet and from the nutritional standpoint, carrots are one of the major sources of carotenoids.

\subsection{Peroxidase activity}

Peroxidase (POD) activity is stimulated both by wounding, physiological stress and the readily availability of phenolic substrates. Partial inhibitions in POD activity of $30 \%$ and $46 \%$ were found, respectively, in HS and UV samples (Fig. 2), when compared to the raw material. These levels of inhibition were relatively maintained up to day 7 followed by an increase in activity $(P<0.05)$ till day 10. In Ctr samples, maintenance in initial POD activity was also registered during 7 days but with higher $(P<0.05)$ levels when compared to pre-treated samples. Also, a significant increase was

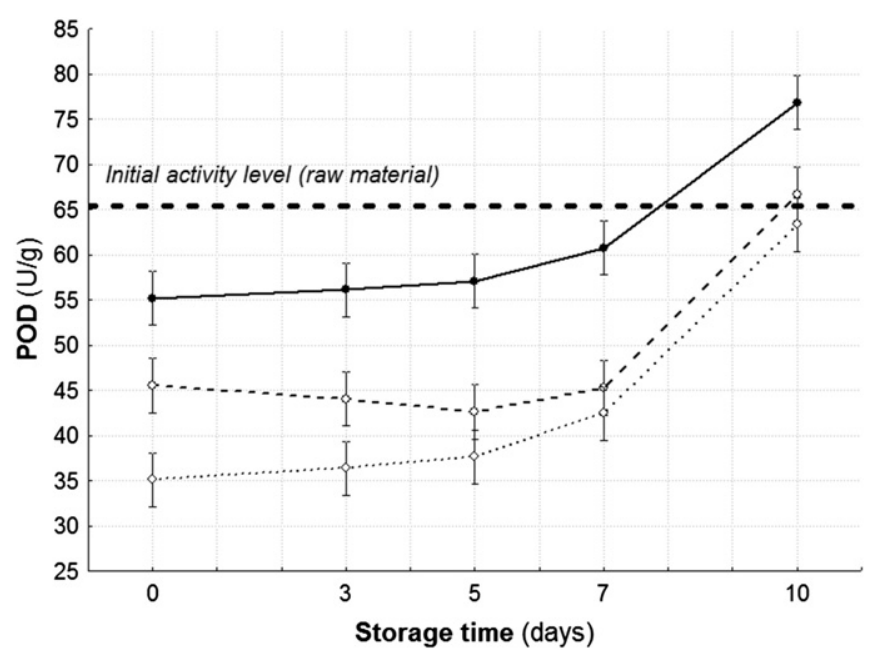

Fig. 2. Effect of abiotic stress treatments on peroxidase (POD) activity of fresh-cut

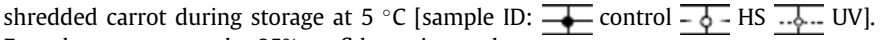
Error bars represent the $95 \%$ confidence interval. found till day 10 surpassing by $20 \%$ the raw material level. The behaviour between pre-treated and Ctr samples points out to the abiotic stress treatments effects, particularly heat shock, over the enzyme activity level, which is in agreement with previous findings (Alegria et al., 2010). Moreover, Artés-Hernández, Robles, Gómez, Tomás-Callejas, \& Artés (2010) while studying the effects of UV-C treatments on the quality of fresh-cut watermelon, found that treated samples showed an initial decrease in enzyme activity (catalase) and suggested that the observed decrease could be evidence for the protective role against active oxygen species induced by oxidative stress in which POD is also involved (Apel \& Hirt, 2004).

\subsection{Headspace analysis}

The headspace analysis $\left(\mathrm{O}_{2}\right.$ and $\left.\mathrm{CO}_{2} \%\right)$ showed that both pretreated samples had significantly reduced metabolic rates in comparison to Ctr samples (Table 2). However, heat shock proved more favourable to the decrease in respiration metabolism since lower $\mathrm{O}_{2} / \mathrm{CO}_{2}$ rates were registered. Reduced respiration rates due to heat shock pre-treatments have already been reported in several fruits and vegetables, namely shredded carrot by different authors (Alegria et al., 2010; Klaiber et al., 2005; Rico et al., 2008; Serrano, Martínez-Romero, Castillo, Guillén, \& Valero, 2004). The same effect was also observed by Baka et al. (1999) in UV-C treated strawberries during postharvest storage.

\subsection{Total mesophilic aerobic count}

Decontamination effects were more expressive in HS samples, where $\mathrm{a} \approx 2.5 \mathrm{Log}$ cycles reduction $(P<0.05)$ in the initial microbial load was found (Table 1 ), and only a 0.6 Log cycle increase in TAPC was registered after 7 days of storage (Fig. 3). This indicates the highly significant effect of heat shock in controlling the microbial development, as also previously reported by Alegria et al. (2010) and Klaiber et al. (2005). The significantly lower microbial development rates found in HS samples support that heat shock is an effective decontamination alternative to microbial control in fresh-cut carrot. Nonetheless, further studies are needed in order to understand this treatment effect over pathogenic flora. It is known that even though heat treatments may result in extended shelf life, they may also provide conditions for pathogens development and

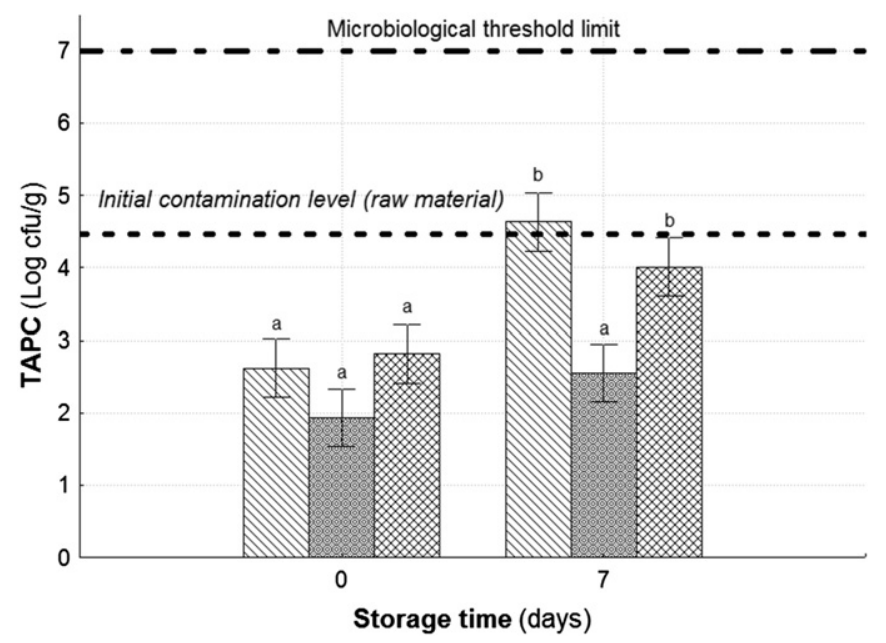

Fig. 3. Effect of abiotic stress treatments on total mesophilic aerobic counts (TAPC) of fresh-cut shredded carrot at day 0 and 7 of storage at $5{ }^{\circ} \mathrm{C}$ [sample ID: VI control HS UV]. Means with the same letter are not significantly different $(P<0.05)$. Error bars represent the 95\% confidence interval. 
thereby increasing the risk for human health problems, as demonstrated in lettuce (Li, Brackett, Chen, \& Beuchat, 2002). UV-C stress treatment achieved a 1.7 Log cycle reduction in the initial microbial load rendering it as effective as chlorine decontamination (1.9 Log cycle). However, UV samples at the 7th day of storage reached counts of $4 \log _{10} \mathrm{cfu} / \mathrm{g}$, with no differences $(P>0.05)$ to $\mathrm{Ctr}$ samples. Noteworthy is that all samples by day 7 had TAPC counts below the microbiological threshold limit to define fresh-cut products shelf life (7 cycles) (PHLS, 2000).

\section{Conclusion}

Both stress pre-treatments showed beneficial effects on the quality of fresh-cut shredded carrot, namely increases in phenolic and carotenoid contents as well as reduced POD activity, during storage. Moreover, heat shock pre-treatment could be considered as an effective alternative to chlorine use in the industrial processing practice of fresh-cut carrot regarding the achieved effects in microbial control and reduced metabolic rates.

Stimulation of bioactive compounds by both pre-treatments proved to be dependent on product storage and need further studies, particularly those related to carotenoid synthesis induced by UV-C irradiation.

In order to improve different quality target areas of the product during storage and according to the observed specific effects of each singular pre-treatment, it is of great interest to test the combination between both abiotic stresses.

\section{Acknowledgements}

The author Carla Alegria acknowledges financial support to Fundação para a Ciência e a Tecnologia (Portugal), via a Doctoral fellowship (SFRH/BD/62211/2009).

\section{References}

Aguayo, E., Escalona, V. H., \& Artés, F. (2008). Effect of hot water treatment and various calcium salts on quality of fresh-cut 'Amarillo' melon. Postharvest Biology \& Technology, 47, 397-406.

Alegria, C., Pinheiro, J., Gonçalves, E. M., Fernandes, I., Moldão, M., \& Abreu, M. (2009). Quality attributes of shredded carrot (Daucus carota L. cv. Nantes) as affected by alternative decontamination processes to chlorine. Innovative Food Science \& Emerging Technologies, 10, 61-69.

Alegria, C., Pinheiro, J., Gonçalves, E. M., Fernandes, I., Moldão, M., \& Abreu, M. (2010). Evaluation of a pre-cut heat treatment as an alternative to chlorine in minimally processed shredded carrot. Innovative Food Science \& Emerging Technologies, 11, 155-161.

Allende, A., Marín, A., Buendía, B., Tomás-Barberán, F., \& Gil, M. I. (2007). Impact of combined postharvest treatments (UV-C light, gaseous $\mathrm{O}_{3}$, superatmospheric $\mathrm{O}_{2}$ and high $\mathrm{CO}_{2}$ ) on health promoting compounds and shelf-life of strawberries. Postharvest Biology \& Technology, 46, 201-211.

Allende, A., McEvoy, J. L., Luo, Y., Artés, F., \& Wang, C. Y. (2006). Effectiveness of twosided UV-C treatments in inhibiting natural microflora and extending the shelflife of minimally processed "Red Oak Leak" lettuce. Food Microbiology, 23, 241-249.

Allende, A., Tomás-Barberán, F. A., \& Gil, M. I. (2006). Minimal processing for healthy traditional foods. Trends in Food Science \& Technology, 17, 513-519.

Apel, K., \& Hirt, H. (2004). Reactive oxygen species: metabolism, oxidative stress, and signal transduction. Annual Review of Plant Biology, 55, 373-399.

Artés-Hernández, F., Robles, P. A., Gómez, P. A., Tomás-Callejas, A., \& Artés, F. (2010). Low UV-C illumination for keeping overall quality of fresh-cut watermelon. Postharvest Biology E' Technology, 55, 114-120.

Baka, M., Mercier, J., Corcuff, R., Castalgne, F., \& Arul, J. (1999). Photochemical treatment to improve storability of fresh strawberries. Journal of Food Science, 64, 1068-1072.

Barry-Ryan, C., \& O’Beirne, D. (1998). Quality and shelf life of fresh cut carrot slices as affected by slicing method. Journal of Food Science, 63, 851-856.

Biehler, E., Mayer, F., Hoffman, L., Krause, E., \& Bohn, T. (2010). Comparison of 3 spectrophotometric methods for carotenoid determination in frequently consumed fruits and vegetables. Journal of Food Science, 75, C55-C61.

Bolin, H. R., \& Huxsoll, C. C. (1991). Control of minimally processed carrot (Daucus carota) surface discoloration caused by abrasion peeling. Journal of Food Science, $56,416-418$.
Corbo, M. R., Speranza, B., Campaniello, D., Amato, D. D., \& Sinigaglia, M. (2010). Fresh-cut fruits preservation: current status and emerging technologies. Current Research, Technology and Education Topics in Applied Microbiology and Microbial Biotechnology, 2, 1143-1154.

Delaquis, P. J., Stewart, S., Toivonen, P. M. A., \& Moyls, A. L. (1999). Effect of warm, chlorinated water on the microbial flora of shredded iceberg lettuce. Food Research International, 32, 7-17.

EN ISO 4833. (2003). Microbiology of food and animal feeding stuffs - Horizontal method for the enumeration of microorganisms - Colony-count technique at $30^{\circ} \mathrm{C}$

Erkan, M., Wang, S. Y., \& Krizek, D. T. (2001). UV-C exposure reduces decay and improves quality of fresh-cut squash. Postharvest Biology \& Technology, 45, 1-9.

Erkan, M., Wang, S. Y., \& Wang, C. Y. (2008). Effect of UV treatment on antioxidant capacity, antioxidant enzyme activity and decay in strawberry fruit. Postharvest Biology E Technology, 48, 163-171.

Fonseca, J. M., \& Rushing, J. W. (2006). Effect of ultraviolet-C light on quality and microbial population of fresh-cut watermelon. Postharvest Biology \& Technology, 40, 256-261.

González-Aguilar, G. A., Villegas-Ochoa, M. A., Martínez-Téllez, M. A., Gardea, A. A., \& Ayala-Zavala, J. F. (2007). Improving antioxidant capacity of fresh-cut mangoes treated with UV-C. Journal of Food Science, 72, 197-202.

Gorocica-Buenfil, M. A., Fluharty, F. L., Bohn, T., Schwartz, S. J., \& Loerch, S. C. (2007). Effect of low vitamin A diets with high-moisture or dry corn on marbling and adipose tissue fatty acid composition of beef steers. Journal of Animal Science, 85(12), 3355-3366.

Guerzoni, M. E., Gianotti, A., Corbo, M. R., \& Sinigaglia, M. (1996). Shelf-life modeling for fresh-cut vegetables. Postharvest Biology E' Technology, 9, 195-207.

Heredia, J. B., \& Cisneros-Zevallos, L. (2009). The effect of exogenous ethylene and methyl jasmonate on pal activity, phenolic profiles and antioxidant capacity of carrots (Daucus carota) under different wounding intensities. Postharvest Biology E Technology, 51, 242-249.

Howard, L. R., Griffin, L. E., \& Lee, Y. (1994). Steam treatment of minimally processed carrots sticks to control surface discoloration. Journal of Food Science, 59(2), 356-358.

Jacobo-Velazquez, D., Martínez-Hernández, G. B., del, C., Rodríguez, S., Cao, C.-M., \& Cisneros-Zevallos, L. (2011). Plants as biofactories: physiological role of reactive oxygen species on the accumulation of phenolic antioxidants in carrot tissue under wounding and hyperoxia stress. Journal of Agricultural and Food Chemistry, 59, 6583-6593.

Ke, D., \& Saltveit, M. E. (1989). Wound-induced ethylene production, phenolic metabolism and susceptibility to russet spotting in iceberg lettuce. Plant Physiology, 76, 412-418.

Klaiber, R. G., Baur, S., Wolf, G., Hammes, W. P., \& Carle, R. (2005). Quality of minimally processed carrots as affected by warm water washing and chlorination. Innovative Food Science \& Emerging Technologies, 6, 351-362.

Lamikanra, O., \& Watson, M. A. (2007). Mild heat and calcium treatment effects on fresh-cut cantaloupe melon during storage. Food Chemistry, 102, 1383-1388.

Lavelli, V., Pagliarini, E., Ambrosoli, R., Minati, J. L., \& Zanoni, B. (2006). Physicochemical, microbial, and sensory parameters as indices to evaluate the quality of minimally-processed carrots. Postharvest Biology \& Technology, 40, 34-40.

Li, Y., Brackett, R. E., Chen, J., \& Beuchat, L. R. (2002). Mild heat treatment of lettuce enhances growth of Listeria monocytogenes during subsequent storage at $5{ }^{\circ} \mathrm{C}$ or $15{ }^{\circ} \mathrm{C}$. Journal of Applied Microbiology, 92, 269-275.

Li, Y., Brackett, R. E., Shewfelt, R. L., \& Beuchat, L. R. (2001). Changes in appearance and natural microflora on iceberg lettuce treated in warm, chlorinated water and then stored at refrigeration temperature. Food Microbiology, 18, 299-308.

Liu, L. H., Zabaras, D., Bennett, L. E., Aguas, P., \& Woonton, B. W. (2009). Effects of UV-C, red light and sun light on the carotenoid content and physical qualities of tomatoes during post-harvest storage. Food Chemistry, 115, 495-500.

Loaiza-Velarde, J. G., Mangrich, M. E., Campos-Vargas, R., \& Saltveit, M. E. (2003). Heat shock reduces browning of fresh-cut celery petioles. Postharvest Biology $\mathcal{E}$ Technology, 27, 305-311.

Loaiza-Velarde, J. G., Tomás-Barberán, F. A., \& Saltveit, M. E. (1997). Effect of intensity and duration of heat-shock treatments on wound-induced phenolic metabolism in Iceberg lettuce. Journal of the American Society for Horticultural Science, 122, 873-877.

Maharaj, R., Arul, J., \& Nadeau, P. (1999). Effect of photochemical treatment in the preservation of fresh tomato (Lycopersicon esculentum cv. Capello) by delaying senescence. Postharvest Biology E Technology, 15, 13-23.

Pan, J., Vicente, A. R., Martínez, G. A., Chaves, A. R., \& Civello, P. M. (2004). Combined use of UV-C irradiation and heat treatment to improve postharvest life of strawberry fruit. Journal of the Science of Food and Agriculture, 84, 1831-1838.

Perkins-Veazie, P., Collins, J. K., \& Howard, L. (2008). Blueberry fruit response to postharvest application of ultraviolet radiation. Postharvest Biology $\mathcal{E}$ Technology, 47, 280-285.

PHLS (Public Health Laboratory Service). (2000). Guidelines for the microbiological quality of some ready-to-eat foods sampled at the point of sale. Communicable Disease and Public Health (CDPH), 3, 163-167.

Ragaert, P., Verbeke, W., Devlieghere, F., \& Debevere, J. (2004). Consumer perception and choice of minimally processed vegetables and packaged fruits. Food Quality and Preference, 15, 259-270.

Rico, D., Martín-Diana, A. B., Barry-Ryan, C., Frías, J. M., Henehan, G. T. M., \& Barat, J. M. (2008). Optimisation of steamer jet-injection to extend the shelflife of fresh-cut lettuce. Postharvest Biology \& Technology, 48, 431-442.

Saltveit, M. E. (2000). Wound induced changes in phenolic metabolism and tissue browning are altered by heat shock. Postharvest Biology \& Technology, 21, 61-69. 
Schenk, M., Guerrero, S., \& Alzamora, S. M. (2007). Response of some microorganisms to ultraviolet treatment on fresh-cut pear. Food and Bioprocess Technology, . doi:10.1007/s11947-007-0029-7.

Serrano, M., Martínez-Romero, D., Castillo, S., Guillén, F., \& Valero, D. (2004). Role of calcium and heat treatments in alleviating physiological changes induced by mechanical damage in plum. Postharvest Biology \& Technology, 34, 155-167.

Singleton, V. L., \& Rossi, J. A. (1965). Colorimetry of total phenolics with phosphomolybdic-phosphotungstic acid reagents. American Journal of Enology and Viticulture, 16, 144-158.
StatSoft Inc.. (2002). STATISTICA (data analysis software system), version 6. (Tulsa, USA).

Turkmen, N., Sari, F., \& Velioglu, Y. S. (2005). The effect of cooking methods on total phenolics and antioxidant activity of selected green vegetables. Food Chemistry, 93, 713-718.

Vandekinderen, I., Van Camp, J., Devlieghere, F., Veramme, K., Denon, Q., Ragaert, P. et al. (2008). Effect of decontamination agents on the microbial population, sensorial quality, and nutrient content of grated carrots (Daucus carota L.). Journal of Agricultural and Food Chemistry, 56, 5723-5731. 